\title{
Immunological Role of the Maternal Uterine Microbiome in Pregnancy: Pregnancies Pathologies and Alterated Microbiota
}

\author{
Jonah Bardos ${ }^{1,2 *}$, Desiree Fiorentino ${ }^{1,2}$, Ryan E. Longman ${ }^{1,2}$ and Michael Paidas ${ }^{1}$ \\ ${ }^{1}$ Department of Obstetrics and Gynecology, Miller School of Medicine, University of Miami, Miami, FL, United States, \\ ${ }^{2}$ Division of Clinical and Translational Genetics, Department of Human Genetics, Miller School of Medicine, University of \\ Miami, Miami, FL, United States
}

OPEN ACCESS

Edited by:

Nicoletta Disimone,

Agostino Gemelli University

Polyclinic, Italy

Reviewed by:

Gerard Chaouat,

INSERM U976 Immunologie, Dermatologie, Oncologie, France

Carlo Ticconi,

Dipartimento Scienze Chirurgiche,

Policlinico Tor Vergata, Italy

*Correspondence: Jonah Bardos

jxb1450@med.miami.edu

Specialty section: This article was submitted to

Mucosal Immunity,

a section of the journal

Frontiers in Immunology

Received: 15 July 2019 Accepted: 15 November 2019

Published: 08 January 2020

Citation:

Bardos J, Fiorentino D, Longman RE and Paidas M (2020) Immunological

Role of the Maternal Uterine Microbiome in Pregnancy:

Pregnancies Pathologies and

Alterated Microbiota.

Front. Immunol. 10:2823.

doi: 10.3389/fimmu.2019.02823
Understanding what happens at the time of embryo implantation has been the subject of significant research. Investigators from many differing fields including maternal fetal medicine, microbiology, genetics, reproductive endocrinology and immunology have all been studying the moment the embryo interacts with the maternal endometrium. A perfect relationship between the uterus and the embryo, mediated by a tightly controlled interaction between the embryo and the endometrium, is required for successful implantation. Any factors affecting this communication, such as altered microbiome may lead to poor reproductive outcomes. Current theories suggest that altered microbiota may trigger an inflammatory response in the endometrium that affects the success of embryo implantation, as inflammatory mediators are tightly regulated during the adhesion of the blastocyst to the epithelial endometrial wall. In this review, we will highlight the various microbiome found during the periconceptual period, the microbiomes interaction with immunological responses surrounding the time of implantation, its effect on implantation, placentation and ultimately maternal and neonatal outcomes.

Keywords: uterine microbiome, pregnancy failure, pre-eclampsia, IUGR, early pregnancy immunology, endometrial micorbiome

\section{INTRODUCTION}

The human body is colonized with over ten times more bacteria than the number of cells (1). Most prior medical research has been focused on disease causing bacteria and only recently, has there been a coordinated focus on studying the resident bacteria, viruses, and fungi collectively called the microbiome. In 2008, the NIH undertook a large human microbiome project in an effort to characterize all the microorganisms living in association with the human body in 300 healthy volunteers (2). The focus was on nasal passages, oral cavity, skin, GI tract, and the urogenital tract including the vagina. Few studies have focused on uterine microbiome as it was originally thought to be a sterile environment. Prior microbiome studies utilized either culture or $16 \mathrm{~S}$ sequence-based technology in determining the bacterial environment. Early work describing the reproductive microbiome came from culture-based approaches (3). However, data from the next generation sequencing of the vaginal microbiome show that many organisms are not identified when culture only based approaches are utilized (4). Early studies suggested only about $1-2 \%$ of bacteria that is present can be picked up on culture (5), while recent studies using next generation sequencing suggest $20-60 \%$ depending on body site (1). More recent reproductive studies utilized 
16S RNA hypervariable region gene sequencing, which can determine the genus and species level of bacteria, but not subspeciation (6). There are both advantages and disadvantages to $16 \mathrm{~S}$ sequencing. $16 \mathrm{~S}$ is significantly cheaper and can be performed on smaller amount of DNA sample since an amplification process is required. However, the amplification process can also introduce an inherent amplification bias making it harder to accurately determine relative abundance of the bacterial species. Additionally, $16 \mathrm{~S}$ technology utilizes a mapping database, meaning the species must have been characterized before by others. When compared with $16 \mathrm{~S}$-based sequencing, shotgun metagenomics can help with the identification of lower taxonomic resolution meaning detecting low abundance microbial communities and can better differentiate between closely related species (7). Essentially, prior work with culture and $16 \mathrm{~S}$ was potentially missing key factors of the reproductive tract microbiome, however there are no studies to date published on shotgun sequencing of the endometrium at the time of an embryo transfer.

Recently there has been a new focus on determining uterine microbiome after a pilot study in 2016 showed that women with a non-lactobacillus dominant (NLD) uterine environment had an almost $40 \%$ drop off in pregnancy rates (8). Another study in 2015, utilized targeted sequencing and microarray data focused on the hypervariable regions of $16 \mathrm{~S}$ rRNA and showed that uterine microbiome at the time of transfer can be characterized by sequencing the tip of the transfer catheter from the embryo transfer (9). Since then, many authors have been attempting to characterize the natural microbiome of the uterus to determine what affect the uterine microbiome has on pregnancy outcomes (10). Current theories suggest that NLD microbiota may trigger an inflammatory response in the endometrium that affects the success of embryo implantation, as inflammatory mediators are closely regulated during the adhesion of the blastocyst to the epithelial endometrial wall.

A perfect relationship between the uterus and the embryo, mediated by a tightly controlled interaction between the embryo and the endometrium, is required for successful implantation. With almost 4 million births annually it is important to continue researching and discovering key factors of healthy pregnancies. Any factors affecting this communication, such as altered microbiome may lead to poor reproductive outcomes.

\section{NORMAL MICROBIOME}

\section{Uterine Microbiome}

For many decades, the uterus was thought to be a sterile environment. Despite being adjacent to the bacterially colonized vagina, it was thought that the cervical mucous maintains uterine sterility. It wasn't until recently that this dogma was challenged. In 1996, Egbase et al. demonstrated that the reproductive tract microbiota can have an effect on IVF outcomes (11).

Is there a healthy "normal" uterine microbiome? This question has been hard to answer. Over the last 15 years about 10 studies have examined uterine microbiome, and over 60 have looked at the reproductive tract microbiome, however most studies to date involved women with pathology $(12,13)$. Prior to 2014 most studies had attempted to utilize culture techniques which has been shown to miss the majority of the pathogens present, as only bacteria whose metabolic needs are met will grow (14). Additionally, highly abundant and fast growing bacteria will dominate and suppress others (15). Thus, it was not until the expansion of next generation sequencing that a better picture of the reproductive microbiome was even possible. In 2015, Franasiak et al. was the first to measure uterine microbiome from catheter tips at the time of an embryo transfer (6). In the studies of healthy women the most consistent phyla have been Firmicutes, Bacteroidetes proteobacteria, and actinobacteria (6, $8-10,16-20)$. The most common genera found in multiple studies have been Lactobacillus and Streptococcus both of which can be found in the vagina and cervix (12). Some studies have found that Lactobacillus is more prominent in women with endometrial polyps or chronic endometritis (21). Multiple studies have suggested that chronic endometritis is associated with recurrent pregnancy loss $(22,23)$. Chronic endometritis (CE) is typically defined as a chronic inflammation of the uterine lining and is associated with the presence of plasma cells on endometrial biopsy $(24,25)$. Numerous microbes have been found in patients with CE including Gonorrhea, Chlamydia, Escherichia coli, Streptococcus, Staphylococcus, Enterococcus fecalis, and non-microbial causes, such as retained tissue. Additionally, endometriosis has been hypothesized to alter the endometrium through increased inflammation and progesterone resistance which can affect implantation, increase risk of miscarriage, poor pregnancy outcomes including pregnancy induce hypertension and preterm birth (26). It would appear that increased inflammation at the endometrial level regardless of the cause may affect implantation and pregnancy outcomes.

A landmark study by Moreno et al. in 2016 suggested that Lactobacillus dominance (>90\%) conferred a protective benefit resulting in increasing implantation rates (8). However, given that only $16 \mathrm{~S}$ methodology was used it is unclear whether certain species or subspecies of Lactobacillus may be capable of conferring this benefit. A recent study on the endometrial microbiota and chronic endometritis reported that Lactobacillus crispatus was less abundant in patients with CE suggesting that there may be certain Lactobacillus spp that is protective (27). More comprehensive whole genome shotgun sequencing (WGS) may help answer this question.

Where does the uterine microbiome come from? There are currently a few theories. The primary theory is ascension from the vagina. While there is a known cervical plug that does protect the uterine environment, we know that, during intercourse, semen is able to ascend into the uterus through small channels in the cervical mucus. Studies have shown evidence of a uterine pump moving radio tagged isotopes from the vagina into the uterus within 15 min of intercourse (28). Other possible methods include hematogenous spread from the gut and transmembrane gut leakage into the peritoneal cavity with retrograde ascension via the fallopian tubes. Dendritic cells and leukocytes traffic bacteria found in the gut and can hematogenously spread bacteria to other locations, such as the uterus (29). One study showed that when genetically labeled Enterococcus fecium was placed in the oral cavity of a mouse it could be detected in 
the placenta (30). Given these possible origins of the uterine microbiome, it is important to understand the microbiome of various anatomical locations.

\section{Vaginal Microbiome}

Since the most likely explanation is ascension, it is important to spend some time understanding the vaginal microbiome. Over the last decade studies involving both $16 \mathrm{~S}$ and metagenomics have examined the microbiome of the human vagina. The human vagina has been shown to harbor predominantly Lactobacillus spp in concentrations as high as $10^{7}-10^{9}$ per gram of vaginal fluid $(10,31,32)$. The high levels of Lactobacillus are known to secrete lactic acid creating the characteristic low PH found in the vagina. This low $\mathrm{PH}$ has been shown to help protect against cervico-vaginal infections $(33,34)$. While the exact reason for Lactobacillus predominance is not known, there are some beneficial aspects of eubiosis. One benefit of the native microbiome is a concept called competitive exclusion. Competitive exclusion is where native microbiome can adapt to be the best nutrient scavenger in that environment, competing with potential invaders for nutrients and in turn starving other pathogens. In reproductive aged women there are five major types of vaginal microbiota or community state types (CST). CST I II, III, and V are all predominantly Lactobacillus. Whereas, CST IV is predominantly a mixture of strict and facultative anaerobes including Gardnerella, Atopobium, Mobiluncus, and Prevotella $(35,36)$. CST IV is commonly broken down into CST IV-A and CST IV-B which is associated with bacterial vaginitis (BV) (36). CST I appears to be more common in Caucasian women and protective against BV, while CST IV is more common in African American and Hispanic women $(37,38)$.

Studies have suggested that the vaginal microbiota is subject to frequent fluctuations (39). In some women, menses or sexual behaviors may trigger transitions between the CSTs at different points in time (36). During times of elevated estrogen, such as immediately prior to ovulation, Lactobacillus tends to stabilize, while during menstruation Lactobacillus tends to decrease (40). While menses appears to alter the composition of the vaginal microbiome, the change appears to depend on the initial CST and other factors, such as the use of pads or tampons (41). The above studies suggest the dynamic nature of the vaginal microbiome, questioning whether one can reliability predict microbiome between menstrual cycles.

There is debate in the literature regarding whether contraceptive options have an effect on the vaginal microbiome. One study suggested that hormonal contraceptives did not have an effect on vaginal microbiota while copper IUDs are associated with an increase in BV (42). Another study suggested that women who took combined oral contraceptives were more likely to have Lactobacillus dominance compared to women who used barrier methods (43). One study suggested that LNG-IUD may increase the risk of candida and decrease Lactobacillus dominance (44). Still another study suggested it was not contraceptive options which drove vaginal microbiome changes but rather the number of sexual partners and the woman's ethnicity (37). Additionally, elevated hormones at the time of implantation could affect the microbiome, for example during a fresh embryo transfer.
A number of other conditions have been associated with an altered vaginal microbiome. Some studies have suggested that Lactobacillus dominated microbiota can be protective against PID (32). CST I appears to decrease the risk of STIs, such has Chlamydia, while CST III appears to be associated with an increased risk of Chlamydia infection (45). CSTs II and V appear to compete with Gonorrhea thereby possibly decreasing the risk of infection (46).

Alterations of the vaginal microbiota may also be responsible for various pregnancy outcomes. During pregnancy menses cease and there is a consistently elevated level of estrogen with a concomitant increase in Lactobacillus dominance (47). Several studies have suggested that altered microbiota are associated with preterm birth (48-50). Preterm premature rupture of membranes (PPROM), chorioamnionitis and early or late miscarriages have also been associated with changes in the vaginal microbiome (5156). One study of the vaginal microbiome on the day of embryo transfer suggested that a lower microbiota index is associated with better IVF outcomes. A recent study suggested that higher levels of vaginal $L$. crispatus is associated with higher chance of pregnancy when utilizing ICSI (57). Neither of these studies included sampling of the upper reproductive tract; therefore, it is hard to draw conclusive results (58). The literature appears to support the concept that alterations in the vaginal microbiome are associated with various poor outcomes and that examining the vaginal along with the upper reproductive tract microbiome at the time of an IVF transfer may shed additional information into the causes of these poor outcomes.

\section{Placental Microbiome?}

Numerous studies have suggested that bacterial infections are the cause of PPROM and preterm labor (59-61). However, until 2014, it was thought that the placenta did not contain its own microbiome. In chorioamnionitis, an inflammatory infectious process of the fetal side of placenta, the most commonly isolated pathogens are Bacteroides species, E. coli, Gardnerella vaginalis, Mycoplasma hominis, Peptostreptococci, Streptococci, and Ureaplasma urealyticum (62). This would suggest that pathologic bacteria can invade the amnion, and chorion from the vagina. Additionally, there are theories of oral placental transmission in patients with poor periodontal disease associated with poor pregnancy outcomes (63). However, the idea that a placenta contains its own healthy microbiome only came about recently after the seminal publication by Aagaard et al. in 2014 (64). This study found multiple phyla in the placental microbiome namely Firmicutes, Tenericutes, Proteobacteria, Bacteroidetes, and Fusobacteria. The initial results were called into question as the techniques did not account for live vs. dead bacteria and did not provide a maternal blood sample to determine if the microbiome was from the maternal villi or from the fetal side (65). Additional studies utilizing high throughput sequencing technology confirmed the presence of a placental microbiome $(66,67)$. Given that the prevailing opinion for many years was that the uterus was sterile, there were theories proposed that the findings were contaminations in either technique or processing. Later studies suggested that DNA reagent kits have their own distinct microbiome called a "kitome" 
(68). Researchers suggested that, in locations with a high biomass, such as the gut, low level contamination of the "kitome" would not be detected, which would explain why many of the gut studies did not have this issue. However, when looking at ultralow biomass locations, such as the placenta or uterus, the results may represent the kit without proper controls (69). A recent seminal study in which the researchers carefully controlled for possible contaminants by utilizing multiple detection methods including culture, qPCR, 16S rRNA gene sequencing and shotgun metagenomics, demonstrated that no resident microbiota could be identified in the placenta. While this study was done with the best technology currently available, if a uterine microbiome exists, as many studies have suggested, it is highly unlikely that the placental and uterine microbiome are not related. It is possible that the placental microbiome is currently undetectable due to ultra-low biomass or the limitations of current technology, however dismissing it as non-existent may be premature.

\section{NORMAL AND ABNORMAL IMMUNOLOGICAL RESPONSES TO PREGNANCY}

The embryo is initially fertilized in the fallopian tube and must evade the immune system, grow and move into the uterus before interacting with the endometrium for implantation. The process of implantation is divided into three key steps: apposition, attachment (adhesion), and penetration (invasion). The immune system plays a role in each step of the embryo's development through the delivery of a live healthy fetus.

An egg is released as a maternal cell containing maternal antigens and would be recognized by the immune system as "self." Sperm then enters the egg typically in the ampullary region of the fallopian tube, triggering multiple changes including production of its own antigens comprised of both maternal and paternal components. Until the embryo starts presenting its own foreign antigens it is viewed as a maternal cell. Once it starts presenting its own antigens it is surrounded by the zona pellucida, a hard shell protecting the embryo from maternal immune cells. Additionally, there are maternal cumulus oophorus cells that provide some protection for the first few days. After the first few days, the embryo must interact with the maternal system. Given that donor embryos are able to implant in surrogates, there must be communication from the embryo that ultimately prevents the maternal immune system from attacking it. It would appear that this communication does not occur immediately given that it takes 4-5 days post-embryo transfer for implantation to occur. During that time a series of events occur, including endometrial priming, immune tolerance and ultimately implantation.

The immune system is usually thought of as a mechanism for the body to defend itself against invaders. Although the egg comes from the woman and would be considered "self," the sperm displays paternal antigens. Shortly after conception the fetus begins displaying major histocompatibility complex (MHC) genes that are a combination of both mother (self) and father (foreign) (70). How then are embryos not attacked and destroyed by the immune system in every pregnancy? The immune system plays an important role in pregnancy success. A combination of multiple strategies are employed to selectively circumvent or engage different aspects of the immune response.

The endometrium has an innate immune system called pattern recognition receptors (PRR) that can detect certain pathogenic receptor patterns locally and mount an inflammatory response. Examples include toll like receptors 1-10, Nod like receptors, and others (71). Some have suggested that local bacteria can also use the PRR as a way to communicate with the host and induce a safe environment (72). A prime example is the way that T-cells are differentiated.

\section{T-Cells}

There are many different types of $\mathrm{T}$ cells that are part of the adaptive immune response. T-helper cells (Th) start out from the same precursor as a Th0 cell. Dendritic cells, a type of antigen producing cell (APC), presents antigens to the naïve Th0 cells and depending on the environmental milieu of cytokines, chemokines, and bacteria the Th0 will differentiate into one of 4 main cell types: Th1, Th2, Th17, and T-regulatory (Treg) (73). Th1 cells are stimulated due to the presence of bacterial DNA and produce pro-inflammatory cytokines, such as TNF and IL12. Th2 cells are stimulated by IL4, IL6, IL10, and IL11 and produce anti-inflammatory cytokines, such as IL4 (74). Th17 is induced based on TGF $\beta$, IL6, and IL21 and produces pro inflammatory cytokines (74). Treg cells are induced by TCR and TGF $\beta$, express Foxp3, CD25 and are key players in inducing tolerance and negative regulation of immune-mediated inflammation (75). Local microbiome can affect whether the TGF $\beta$ increased Th17 or Treg cell population (76). Treg cell dysfunction is associated with autoimmune, auto-inflammatory disorders, allergies, as well as acute and chronic infections (77).

The embryo must convince the body that it should be tolerated. Treg cells take "non-self" antigens that are presented to it and promote active tolerance to those antigens by downregulating the Th1 and Th17 responses (70, 78, 79). Treg cells inhibit additional T-cell proliferation and proinflammatory cytokine productions by producing TGF $\beta$ and IL10 while suppressing B cell proliferation, antibody production, NK cell cytotoxicity, as well as dendritic and macrophage maturation and activation (80-82).

Treg cells help down-regulate immune response against the embryo to allow for intimate interaction with the endometrial lining (70). Treg cells are recruited to the uterus shortly after conception which is an important time for the fledgling embryo's existence. Apposition, implantation and early placental morphogenesis is a key time in which the embryo begins to interact directly with the maternal immune system. Poor immune tolerance at this point could result in shallow implantation which has been implicated as a possible cause of IUGR and miscarriage $(83,84)$. Additionally, problems in early placental development have been linked with pre-eclampsia, an increasingly common morbidity of late pregnancy (85). There is evidence that the local microbiome can induce a shift to Th1 and away from Treg cell dominance. For example, Bacteroides is thought to increase the presence of Th1 cells (86). An upregulation of Th1 will cause an 
increase in local inflammation and an augmented local immune response. As mentioned prior, it would appear that increased inflammation at the endometrial level regardless of the cause may affect implantation and pregnancy outcomes. However, beneficial microbiome can increase uterine Treg cells locally thereby downregulating the immune response and inducing tolerance to a specific species or a pregnancy (13).

\section{Blast Development}

In vivo, in the first $48 \mathrm{~h}$ post-fertilization the embryo is encased in a hard-outer shell called the zona pellucida. Within 2 days, the embryo moves from the fallopian tubes into the uterus where it floats while undergoing cleavage and differentiation into a blastocyst. About 5-6 days post-fertilization, the embryo hatches from the zona pellucida exposing its outer trophoblasts to the endometrial lining (87). Embryos display cytokine receptors from conception until implantation. Cytokines play a key role in embryo development, gene expression, cell number, embryo competence and viability $(88,89)$. In healthy women, embryotrophic factors, such as GM-CSF, CSF1, LIF, HB-EGF, IGF1, and IGF2 all act to promote blastocyst development, increase blast cell numbers and gene expression. Decreased cell number and poor trophoblast development can cause changes in placental structure and nutrient transport functions leading to pregnancy loss or developmental damage (90, 91). GMCSF is produced by the uterine epithelial cells, exerting a pro survival and anti-stress effect required for fetal viability and offspring health (92). Embryotoxic cytokines, such as TNF, IFNG, and TRAIL are stimulated during inflammation or local infections via toll like receptors and induce apoptosis and inhibit embryo development (93). Other environmental factors, such as hyperglycemia and obesity can also induce embryotoxic chemokines which may explain why these conditions are associated with poor pregnancy outcomes. This complex balancing act between embryotrophic vs. embryotoxic cytokines acts a physiologic control enabling pregnancy when the uterus is under optimal conditions and inhibiting pregnancy when the conditions are sub-optimal. Obviously, these alone are not the only determinants, as obese diabetic women do get pregnant, however, the delicate cytokine balance, controlled by many factors including the local microbiome, can have a large impact on reproductive outcomes.

\section{Endometrial Receptivity}

Sex steroids also play an important role in modifying the immune response and preparing the uterine lining for implantation. In the proliferative phase, estrogen stimulates proliferation and differentiation of endometrial cells as well as pro inflammatory cytokines, such as CSF1, GM-CSF, INFG, and TNF. During the luteal phase, progesterone stimulates the mesenchymal cells to prepare for implantation and suppresses the pro inflammatory cytokines by inhibiting epithelial cell productions of GM-CSF 1 and IL1. Progesterone also enhances the expression of IL8 and attracts uterine NK cells (70). Estrogen increases Treg attracting chemokines, CCL3, 4, and 5, while progesterone sustains the Treg population and increases their suppressive function (94). Additional endometrial chemokines, such as
LIF and IL11 are essential for decidual and vascular changes required to allow proper trophoblastic invasion (95). It has been suggested that in patients with endometriosis the endometrial tissue may have progesterone resistance which could explain the increased inflammation and poor pregnancy outcomes (96). Placental trophoblasts secrete TGF $\beta$ which helps suppress immunity, and assists in inducing Treg cells at the placental maternal interface $(70,97)$. Excess inflammatory cytokines, such as TNF, IFNG, and IL2, during the implantation period can act to skew the adaptive immune response away from Treg cells and toward cytotoxicity (98). Excess inflammatory factors are found during local infection and times of nutritional or metabolic stress, thereby helping the body suppress pregnancy during unfavorable conditions; leading to failed implantation or pregnancy loss. Excess inflammation may also be found when the host microbiome is altered thereby conferring negative effects on implantation and outcomes.

Other cells also play a role in controlling immune response at the uterine level. Uterine macrophages produce Treg stimulatory cytokines TGF $\beta$, PGE2, and IL10 (99). Decidual macrophages also secrete matrix proteinases which can help with trophoblast invasion (100). Dendritic cells present antigens to naive T cells to stimulate Treg cell activation before implantation (101). Uterine NK cells are involved in the endometrial remodeling needed for implantation (102). Seminal fluid appears to play a role in driving leukocytes to the uterus. Seminal fluid can stimulate the expansion of the Treg population via TGF $\beta$ and PGE2 along with paternal antigens and help inhibit the activated Treg cells from leaving the uterus, inducing tolerance to the embryo.

The embryo also plays a role in its own fate by secreting factors. PreImplantation Factor (PIF) is secreted only by viable embryos and can be measured in embryo culture media. PIF can be seen in maternal circulation as soon as 4 days postembryo transfer indicating that it does come from the embryo. When PIF is seen in maternal plasma, the chance of normal pregnancy is significantly higher (103). PIF appears to have anti inflammatory effects. It provokes global immune regulation by binding ligands to CD14 monocytes/neutrophils and to T and $\mathrm{B}$ cells promoting the required Th2/Th1 cytokine ratio. It also appears to affect genes involved in oxidative stress, protein misfolding, and platelet activation.

Human chorionic gonadotropin (hCG) has many different roles during early pregnancy including immunosuppression. Its' most well-known and crucial role is to promote corpus luteal progesterone production for the first 3-4 weeks after implantation (104). In addition, hCG is thought to help promote placentation and angiogenesis by recruiting and promoting VegF and Treg function necessary for decreasing local inflammation (105).

The immune environment during the peri-conceptual period is controlled by many factors, including cytokines, chemokines and leukocyte lineages. These factors are intertwined with ovarian steroid hormones, seminal fluid, diet, nutrition, metabolism, obesity, infections, and the microbiome to influence the balance between embryotrophic and embryotoxic milieus and ultimately a successful or unsuccessful pregnancy. 


\section{UTERINE EMBRYO SIGNALING AND IMPLANTATION}

As mentioned previously there are three stages to implantation: apposition, adhesion, and invasion. We have discussed how the microbiome cytokine influence can affect the competency of the embryo. We will now briefly discuss each stage of implantation to understand how the microbiome could help or hinder the successful progression of pregnancy. Researchers still do not fully understand how implantation works. Decidualization is the transformation of the endometrium into a receptive state prior to the presence of the embryo. Between 6 and 10 days after ovulation the point in which the endometrium is receptive occurs, called the window of implantation. Once the embryo reaches the primed endometrium there is a process of selection, apposition, attachment, implantation, and ultimately placentation that requires intricate embryo uterine interactions to occur in a synchronized fashion for pregnancy to be sustained. While the main drivers of these processes are hormonal control, additional local cytokine factors may play an important role. Alterations from the natural microbiome may affect the local cytokine/chemokine profile thereby affecting implantation.

\section{Apposition and Adhesion}

Approximately 6-7 days after fertilization the blastocyst makes contact with the uterine wall in a transient dynamic process called apposition. Microvilli extending from the syncytiotrophoblast interact with small microprotrusions from the uterine epithelial cells called pinopodes. This step is unstable and must occur first before the embryo can firmly attach to the wall. The interaction between the uterine cell wall and the embryo activates cytokine signaling and remodeling of the cytoskeleton of the epithelial layer. Decidual macrophages secrete matrix proteinases which can help with trophoblast invasion (100). Matrix metalloproteinases are important players in trophoblast invasion and are regulated by cytokines and tissue inhibitors (TIMPs) (106). TIMPs are upregulated by TGF $\beta$ inhibiting proper matrix degradation which can affect implantation (107). Increased TGF $\beta$ can be caused by colonizing microbes (76). Tight junctions are disrupted mediated by local cellular communication (108). Uterine NK cells are also involved in the endometrial remodeling needed for implantation (109).

\section{Invasion}

The final stage is invasion during which the syncytiotrophoblast invade the uterine epithelium. By approximately day 10 after fertilization, the blastocyst is surrounded by uterine tissue and the epithelium regrows over the implantation site. The cytotrophoblasts continue to expand until they reach the myometrium and the uterine spiral arteries leading to the establishment of uteroplacental circulation (110). The resulting uterine arterioles are composed of both maternal and fetal cells, underscoring the importance of immune tolerance in proper placentation. Implantation is the result of an intricate bi-directional dialogue between the embryo and endometrium mediated by a host of factors regulating the invading cells from cytokines and growth factors to steroid hormones and proteinases (111). Dysfunctional placentation can have clinical implications due to either excessive or inadequate invasion. Excessive invasion of the cytotrophoblasts can lead to abnormally strong attachment or a morbidly adherent placenta, such as an accrete, increta, or percreta depending on depth of invasion. Inadequate invasion has been implicated in pre-eclampsia, and IUGR $(112,113)$.

\section{CURRENT UNDERSTANDING OF PRE-ECLAMPSIA}

After years of study, the mechanisms by which pregnancy incites or aggravates hypertension remain unknown and hypertensive disorders continue to play an important role in maternal morbidity and mortality worldwide. Preeclampsia is more likely to occur in women who are exposed to chorionic villi for the first time (nulliparous women); are genetically predisposed to hypertensive disorders of pregnancy; have preexisting conditions associated with endothelial cell activation or inflammation including diabetes, cardiovascular or renal disease, or immunologic disorders; and in women who are exposed to a superabundance of chorionic villi (as in the cases of twins or molar pregnancies). Additionally, while a fetus is not required for the development of preeclampsia (as in molar pregnancies), the presence of chorionic villi is. A case series published in 2008, reported that PEC may develop even when the chorionic villi are extra-uterine as in the case of an abdominal pregnancy (114). Regardless of the underlying cause, the events leading to PEC all result in systemic vascular endothelial damage leading to transudation of plasma, vasospasm, and thrombotic sequelae.

Currently, the four most likely explanations for the development of PEC include: immunological maladaptive tolerance between maternal, paternal, and fetal tissues; placental implantation with abnormal trophoblastic invasion; oxidative stressors resulting in endothelial cell dysfunction; or genetic factors including predisposing genes and epigenetic influences.

Loss of maternal immune tolerance to paternally derived antigens is a possible etiology of preeclampsia (115). This hypothesis is supported by the fact that preeclampsia is more likely to occur when the formation of blocking antibodies to paternal antigens might be impaired. For instance, there is an increased risk in first pregnancies or pregnancies with a new partner and molar pregnancies which have an increased paternal antigenic load. Additionally, pregnancies with a fetus with trisomy 13 who have elevated antiangiogenic factors arising from the presence of an extra copy of soluble fms-like tyrosine kinase 1 which is located on chromosome 13 have increased risk of preeclampsia $(116,117)$. A recently published study indicated that the angiogenic factors placental growth factor, soluble fmslike tyrosine kinase 1, and soluble endoglin are biomarkers with predictive potential for preeclampsia. The soluble fmslike tyrosine kinase 1/placental growth factor ratio is able to accurately predict the short term absence of preeclampsia and suggest the likelihood of adverse events within 4 weeks (118). Further, another study from April 2019 demonstrated that $\mathrm{CD}^{+}$, 
$\mathrm{CD}^{-}{ }^{-}$, FoxP3 $^{-} \mathrm{T}$ cells were associated with uteroplacental acute atherosis which is a common lesion of the maternal spiral arteries in the decidua basalis in preeclampsia (119). The decidua basalis layer forms the maternal-fetal immunologic interface where fetal extra-villous trophoblasts interact with maternal immune cells. Immune maladaptation may also play a role in the pathophysiology of preeclampsia. Extra-villous trophoblasts express HLA-C which is a ligand for killer immunoglobulinlike receptors (KIR) on NK- and T-cells. The combination of maternal KIR-B haplotype and fetal HLA-C2 has been shown to be significantly associated with acute atherosis. Thus, it seems that interactions between fetal HLA and activating KIRs on maternal decidual NK-or T-cells may promote local decidual vascular inflammation and trigger the formation of acute atherosis (120). This supports the theory that inadequate maternal tolerance of invasive trophoblast, which can be due to a shift in the immune system against tolerance, i.e., the Th1/Th2 ratio, can trigger poor trophoblast invasion and the occurrence of preeclampsia (121).

As previously discussed, normal implantation requires invasion of the syncytiotrophoblast into the uterine epithelium, ultimately resulting in remodeling of the uterine spiral arteries to create a dilated low resistance vessel. In pregnancies complicated by preeclampsia, there is thought to be incomplete invasion of the spiral arteriolar wall leading to small caliber, high resistance vessels with correlation shown between the degree of syncytiotrophoblast dysfunction and the severity of the resulting preeclampsia $(122,123)$. These high resistance vessels impair placental blood flow resulting in diminished perfusion and a hypoxic environment. There is subsequently a release of placenta microparticles which incites a systemic inflammatory response $(124,125)$.

Decreased placental perfusion from dysfunctional placenta implantation results in repeated ischemia/reperfusion episodes which creates a favorable environment for developing oxidative stress and stimulates the production and secretion of proinflammatory cytokines as well as vasoactive compounds. Cytokines, such as tumor necrosis factor alpha and interleukins contribute to systemic oxidative stress which is characterized by reactive oxygen species and free radicals that lead to the formation of lipid peroxides (126). These lipid peroxides then generate highly toxic radicals that injure vascular endothelial cells, modify nitric oxide production by the cells, and interfere with prostaglandin balance. The above cascade results in systemic endothelial dysfunction characterized by vascular inflammation and constriction. Other consequences of oxidative stress include production of lipidladen macrophage foam cells that are seen in acute atherosis, activation of microvascular coagulation, and increased capillary permeability. The important role of oxidative stress in the pathophysiology of preeclampsia is further supported by a study in which concentrations of maternal oxygen free radical were measured in 52 women with and without preeclampsia. Maternal serum concentrations of oxygen free radicals were significantly increased in the preeclampsia group relative to the normal group (127). Some researchers conclude that oxidative stress appears to be the central component of both placental and endothelial dysfunction, the causative etiology of preeclampsia (128).

Preeclampsia is a multifactorial condition with a strong genetic component. Immune maladaptation, endothelial function, and oxidative stress all encompass genetic factors that could be responsible for the pathogenic changes that take place in preeclampsia. Additionally, there is evidence that paternal genes significantly increase the risk of preeclampsia (129). In a study of $\sim 1.2$ million births in Sweden, a genetic association for preeclampsia was noted (130). The hereditary risk of preeclampsia most often cited is $20-40 \%$ for daughters of pre-eclamptic mothers and $11-37 \%$ for sisters of preeclamptic women (131). The hereditary predisposition for preeclampsia most likely results from the interactions of hundreds of genes and it is doubtful that any one gene will be found responsible. Epigenetic alterations have also been noted in preeclampsia including alterations of methylation in the placenta of pre-eclamptic patients. Additionally, it is hypothesized that antiangiogenic and cytotoxic factors released by the placenta in preeclampsia have the potential to induce epigenetic modifications in maternal tissues (132).

\section{CURRENT UNDERSTANDING IN CAUSES OF IUGR}

Fetal growth restriction, also known as intrauterine growth restriction (IUGR), is a common pregnancy complication that has been linked with a variety of adverse perinatal outcomes. The precise mechanism by which normal growth occurs is unknown, but IUGR is usually the end result of maternal, fetal and placental causes or a combination thereof. Although the primary pathophysiologic mechanisms underlying these conditions are different, they often result in the same final common pathway of suboptimal uterine-placental perfusion and fetal nutrition.

Multiple placental, cord, and uterine anomalies are associated with poor fetal growth. Placental insufficiency may be due to abnormal placental development or placental damage. Several placental abnormalities including chronic abruption, infarction, circumvallate shape, chorioangioma, velamentous cord insertion, and umbilical artery thrombosis have been shown to lead to uteroplacental insufficiency and IUGR (133). Inflammation may contribute to placental damage and abnormal development as inflammatory mediators promote thrombosis (133). Hypoperfusion of the placental site may also arise secondary to implantation site disorders. Brosens et al. postulated that there is a partial progesterone resistance in the fetal uterus at the time of birth that may persist into the adolescent years resulting in compromised physiological transformation of the spiral arteries. This theory is supported by the fact that major obstetric syndromes due to impaired placental bed spiral artery remodeling, including preeclampsia, growth restriction, and preterm labor, are all more prevalent in teenage pregnancies (134).

Maternal medical comorbidities, especially those with vascular disease or thrombosis, are also associated with IUGR via poor placental perfusion. Chronic vascular disease, 
including maternal ischemic heart disease, is associated with higher rates of preeclampsia and IUGR (135). Chronic renal insufficiency is frequently accompanied by underlying hypertension and vascular disease and thus, often also results in IUGR. Additionally, pre-gestational diabetes, especially when complicated by vascular or renal disease, and disease states resulting in chronic uteroplacental hypoxia like preeclampsia, chronic hypertension and asthma can lead to significantly reduced birthweight. Maternal conditions, like antiphospholipid syndrome, increase the risk of ischemic placental dysfunction resulting in a similar outcome of poor perfusion and decreased growth (136). Other maternal factors may contribute to IUGR without directly impacting the placenta. These include poor maternal nutrition and eating disorders; constitutionally small mothers, particularly when combined with poor gestational weight gain, and social issues (137-139).

Exposure to drugs and teratogens during pregnancy are associated with IUGR. Cigarette, opiate, alcohol, and cocaine use cause fetal growth restriction directly and by decreasing maternal food intake $(140,141)$. Even prescription medications like anticonvulsants, antineoplastic agents, and antithrombotic drugs are teratogens and can result in fetal growth restriction $(142,143)$. Multifetal gestation and fetal malformations are also seen in association with intrauterine growth restriction. In one study of pregnancies complicated by gastroschisis, one-third of neonates had birthweights less than the 10th percentile (143).

Still other etiologies of fetal growth restriction interact with the placental, maternal, and fetal compartments. The most important of these include infections and genetic anomalies. In their text book Maternal Fetal Medicine: Principles and Practice, Creasy et al. postulated that fetal infections account for $5-10 \%$ of IUGR with malaria accounting for most cases of infection-related fetal growth restriction worldwide (144, 145). Additionally, rubella, CMV, toxoplasmosis, varicella, and syphilis have all been shown to have a causal relationship with fetal growth restriction (146-149). Under normal conditions, maternal genes have the main influence on birthweight (150). Fetal aneuploidy is responsible for up to $5 \%$ of IUGR diagnosed at any point of pregnancy and up to $20 \%$ of IUGR diagnosed in the first half of pregnancy (151). Trisomy 13 and 18 are usually associated with more severe IUGR while in Trisomy 21 the growth restriction is typically mild (152). Even confined placental mosaicism is associated with low birth weight and adverse pregnancy outcomes (153). In summary there are many possible etiologies including inflammation and abnormal initial placentation all causing the same final pathway of IUGR.

\section{HOW MICROBIOME AFFECTS IMMUNITY IN OTHER AREAS OF THE BODY AND IMPLICATIONS FOR THE UTERUS}

Studies looking at germ free mice revealed that without bacteria there are profound effects on mouse lymphoid tissue, suggesting that bacteria is important for immune development (154). The
GI tract is the most studied area of human microbiome to date as the majority of immune system interactions occur within the gut (76). It contains the most abundant population of microorganisms with over 5,000 bacteria taxa (155). The gut microbiome is colonized at birth with initial differences noted depending on mode of delivery (156). Unlike the uterine microbiome that undergoes changes with menses, once a child is about 2.5 years old their microbiome remains relatively stable until age 65 (156). Although it is stable, it can be quickly altered by host factors, such as antibiotics, travel or high fat diets (157). Dysbiosis in the gut has been linked to many diseases, ranging from liver disease and GI cancer to metabolic disease, respiratory disease, mental health disorders and autoimmune disorders (158). The suggested reasoning is that the changes in the microbiome can increase immune system sensitivity to pathogens thereby causing increased inflammation (159). The most potent causes of dysbiosis are pathogens in the gut. There is evidence that altered oral flora, such as during periodontal disease can cause many systemic disorders, such as atherosclerosis and poor pregnancy outcomes (160, 161). Chronic low-level periodontal disease may induce low level chronic systemic inflammation (162). There are theories as to why dysbiosis causes these changes. Alterations in gut microbiota has profound effects on the T-cell mediated autoimmune and inflammatory responses. The gut microbiota is known to provide signaling for proper development, differentiation and epigenetic influences of immune cells (154). Dysbiosis can transition the chemokine profile to cause a Th17 pro inflammatory dominance, which can trigger not only local, but also systemic inflammatory responses and has been linked to Alzheimer's disease $(159,163)$.

In 2012, Hooper and Macpherson described immunological benefits of host intestinal microbial homeostasis: (1) Host microbiome restricts direct contact between epithelia and pathogenic microbes, (2) Host microbiome anatomically limits the exposure of pathogenic bacteria to the systemic immune system, and (3) Host microbiome can aid in the rapid detection and killing of bacteria upon barrier breach (154).

Some of the suggested theories is that is that host bacteria (microbiome) have the chance to adapt to their environment. The adaptation process allows them to specialize in nutrient utilization thereby depleting nutrients that would otherwise be available for invading pathogens. This process, called colonization resistance, could support the potential importance of a healthy uterine microbiome (164). Additionally, symbiotic bacteria may also compete for the cell's receptors. For example, one study utilizing an in vitro model found that the presence of lactobacillus in the reproductive tract prevents gonorrhea from attaching to endometrial cells (46).

The host microbiome may also help support a healthy and intact epithelial barrier thereby preventing pathogen access to the cell. In the gut, studies have suggested that the microbiome can affect epithelial cell differentiation, maintenance and adaptation and modulate epithelial cell permeability (165, 166). Given that the uterus frequently undergoes shedding and regrowth, microbial support could play an important role in 
maintenance of the epithelial tissue. Conversely, dysbiosis could be an underlying cause of poor endometrial thickening and abnormal placentation.

\section{HYPOTHESIS FOR HOW ALTERED MICROBIOME AFFECTS PEC AND IUGR}

As discussed above, studies have shown that changes in the microbiome can prompt inflammation. For example, specific oral pathogenic bacteria including Fusobacterium nucleatum, Porphyromonas gingivalis, Filifactor alocis, Campylobacter rectus are associated with both periodontitis and the development of pregnancy disease (167). The involvement of systemic inflammatory responses in pregnancies complicated by PEC and IUGR has led to the theory that maternal infections may be important factors in the pathogenesis of pregnancy complications. At the base of all possible etiologies of preeclampsia, there exists the same common result of systemic vascular endothelial damage. The remodeling of the spiral arteries in the decidua basalis is a critical step in the establishment of a healthy pregnancy. The decidua basalis is the maternal fetal immunologic interface and it has been shown that local inflammation in area can lead to acute atherosis and poor trophoblast invasion. Additionally, studies have shown that women with asymptomatic bacteriuria, urinary tract infection, and chronic pyelonephritis are at increased risk for preeclampsia $(168,169)$. Another study by den Hollander et al. found that Helicobacter pylori, as a cause of chronic inflammatory conditions, is associated with an increased risk of PEC (170). Further, Li Juan et al. demonstrated that preeclampsia is associated with a disrupted gut microbiota composition compared with that of women who had uncomplicated pregnancies (171). In a recent review of the current knowledge about the possible association between the microbiome and the development of preeclampsia, Dunn et al. did a comprehensive literature search and reported that overall, five groups of investigators studied the microbiome of PEC (172). In two of the studies, the placenta site was analyzed; in the remaining three, the mouth, gut, or an intra-amniotic site was examined. Some findings supported the association between pathogenic bacteria and PEC, but specific pathogenic organisms were not identified and further research is warranted. In a 2015 study, placental tissue samples from women with and without preeclampsia were collected and screened for the presence of bacteria by PCR for 16s rRNA and next generation sequencing. $12.7 \%$ of the tissue from women with PEC was PCR positive, while all of the placentas of the control group were negative (173).

While the etiology of growth restriction has also not been elucidated precisely, it seems to result from poor uterineplacental perfusion. It is known that inflammation may contribute to placental damage and that any maternal disease state that can lead to utero-placental hypoxia, like preeclampsia, can result in the development of intrauterine growth restriction. In this way, it is possible that the maternal microbiome could modulate the development of growth restriction by influencing the inflammatory state of the placenta and uterus. One example of systemic inflammation contributing to the development of pregnancy complications can be seen in the study of Den Hollander et al. They reported that $H$. pylori seropositivity with CagA-positive strains, which are associated with higher levels of systemic inflammation than CagA-negative strains, is associated with IUGR (170). Additionally, a study analyzing the characteristics of gut microbiota in IUGR and normal birth weight piglets in the first $12 \mathrm{~h}$ of life found an imbalanced inflammatory and plasma metabolome profile in the IUGR piglets (174). The gut microbiome is believed to be colonized at birth with differences seen based on mode of delivery and thus, presumably, exposure to the maternal microbiome. To our knowledge no studies have been done, to date, evaluating the uterine microbiome at the time of implantation and its effect on the development of obstetrical complications of pregnancy including preeclampsia and growth restriction.

\section{SUMMARY OF EFFECTS OF MICROBIOME ON UTERINE IMMUNE SYSTEM}

Based on both in vitro mouse and gut studies there are a likely four possible ways in which local microbiome can affect the clinical sequalae of pregnancy. It is possible that the microbiome cause alterations in regional signaling pathways. For example, as mentioned before, alterated microbiome can cause an abnormal inflammatory response through the uterine toll like receptors. When these receptors are activated they can alter the cytokine milieu swaying the local response to a pro inflammatory and anti-tolerance immune cell response. A second method as previously mentioned can be through the alteration of the endometrial epithelial barrier integrity. Certain pathogens cause a localized decrease in matrix degradation proteins which may affect placentation. A third possible method is that the local microbiome has a competitive advantage, as it has adapted to be the best nutrient scavenger in that area and can usually starve out possible invading species in a process called competitive exclusion. Lastly, microbes can secrete metabolites, such as short chain fatty acids that suppress growth of certain species. Taken together, the natural microbiome can have an impressive effect on the local interactions between the embryo and endometrium with implications on implantation, placentation and embryonic growth, ultimately affecting pregnancy and pregnancy outcomes.

\section{CONCLUSION-FUTURE AREAS OF RESEARCH}

Current data has yet to support what the characterization of a normal uterine microbiome. However, it is hard to believe that a mucosa that is in close proximity to the vagina with a wellcharacterized microbiome with regular sperm penetration that microbes do not get through the cervix. The question remains as to whether those microbes are transient and whether a host microbiome controls that transience. Prior studies have been limited so far by $16 \mathrm{~S}$ only sequencing with an amplification bias and potentially missing any species not currently in 
the bioinformatics database. It is highly likely that a normal endometrial microbiome does exist. It is possible that it is of very low level and therefore easily subject to sampling contamination which could explain why we have not yet discovered the "normal microbiome," however it is likely present and given what we know about gut microbiome, it likely plays a role in immunoregulation, endometrial remodeling, pregnancy implantation and placentation. Future research should include sampling of multiple possible contamination sites as well as utilizing shotgun metagenomics for a better understanding of all the pathogens at play.

\section{REFERENCES}

1. NIH Hmp Working Group, Peterson J, Garges S, Giovanni M, McInnes P, Wang L, Schloss JA, et al. The NIH human microbiome project. Genome Res. (2009) 19:2317-23. doi: 10.1101/gr.096651.109

2. About The Human Microbiome. NIH Human Microbiome Project-About the Human Microbiome. Available online at: https://hmpdacc.org/hmp/ overview/ (accessed November 8, 2018).

3. Selman H, Mariani M, Barnocchi N, Mencacci A, Bistoni F, Arena S, et al. Examination of bacterial contamination at the time of embryo transfer, and its impact on the IVF/pregnancy outcome. J Assist Reprod Genet. (2007) 24:395-9. doi: 10.1007/s10815-007-9146-5

4. Verhelst R, Verstraelen H, Claeys G, Verschraegen G, Delanghe J, Van Simaey L, et al. Cloning of $16 \mathrm{~s}$ rRNA genes amplified from normal and disturbed vaginal microflora suggests a strong association between atopobium vaginae, Gardnerella vaginalis and bacterial vaginosis. BMC Microbiol. (2004) 4:16. doi: 10.1186/1471-2180-4-16

5. Wade W. Unculturable bacteria-the uncharacterized organisms that cause oral infections. J R Soc Med. (2002) 95:81-3. doi: 10.1258/jrsm.95.2.81

6. Franasiak JM, Werner MD, Juneau CR, Tao X, Landis J, Zhan Y, et al. Endometrial microbiome at the time of embryo transfer: next-generation sequencing of the 16 s ribosomal subunit. J Assist Reprod Genet. (2016) 33:129-36. doi: 10.1007/s10815-015-0614-z

7. Li F, Chen C, Wei W, Wang Z, Dai J, Hao L, et al. The metagenome of the female upper reproductive tract. Gigascience. (2018) 7:Giy107. doi: 10.1093/Gigascience/Giy107

8. Moreno I, Codoñer FM, Vilella F, Valbuena D, Martinez-Blanch JF, JimenezAlmazán J, et al. Evidence that the endometrial microbiota has an effect on implantation success or failure. Am J Obstet Gynecol. (2016) 215:684-701. doi: 10.1016/j.ajog.2016.09.075

9. Tao X, Franasiak JM, Zhan Y, Scott RT III, Rajchel J, Bedard J, et al. Characterizing the endometrial microbiome by analyzing the ultra-low bacteria from embryo transfer catheter tips in IVF cycles: next generation sequencing (NGS) analysis of the 16s ribosomal gene. Hum Microb J. (2017) 3:15-21. doi: 10.1016/j.humic.2017.01.004

10. Chen C, Song X, Wei W, Zhong H, Dai J, Lan Z, et al. The microbiota continuum along the female reproductive tract and its relation to uterine-related diseases. Nat Commun. (2017) 8:875. doi: 10.1038/s41467-017-00901-0

11. Egbase PE, al-Sharhan M, al-Othman S, al-Mutawa M, Udo EE, Grudzinskas JG. Incidence of microbial growth from the tip of the embaryo transfer catheter after embryo transfer in relation to clinical pregnancy rate following in-vitro fertilization. Hum Reprod. (1996) 11:1687-9.

12. Koedooder R, Mackens S, Budding A, Fares D, Blockeel C, Laven J, et al. Identification and evaluation of the microbiome in the female and male reproductive tracts. Hum Reprod Update. (2019) 25:298-325. doi: 10.1093/humupd/dmy048

13. Baker JM, Chase DM, Herbst-Kralovetz MM. Uterine microbiota: residents, tourists or invaders? Front Immunol. (2018) 9:208. doi: 10.3389/fimmu.2018.00208

14. Nadkarni MA, Martin FE, Hunter N, Jacques NA. Methods for optimizing DNA extraction before quantifying oral bacterial

\section{AUTHOR CONTRIBUTIONS}

JB and DF were responsible for the manuscript preparation. RL and MP were responsible for the important editorial input.

\section{FUNDING}

Funding for the research was provided by the Department of Human Genetics and the Department of Obstetrics and Gynecology at the University of Miami Miller School of Medicine.

numbers by real-time PCR. FEMS Microbiol Lett. (2009) 296:45-51. doi: 10.1111/j.1574-6968.2009.01629.x

15. Hiergeist A, Gläsner J, Reischl U, Gessner A. Analyses of intestinal microbiota: culture versus sequencing. ILAR J. (2015) 56:228-40. doi: 10.1093/ilar/ilv017

16. Fang RL, Chen LX, Shu WS, Yao SZ, Wang SW, Chen YQ. Barcoded sequencing reveals diverse intrauterine microbiomes in patients suffering with endometrial polyps. Am J Transl Res. (2016) 8:1581-92.

17. Verstraelen H, Vilchez-Vargas R, Desimpel F, Jauregui R, Vankeirsbilck N, Weyers $\mathrm{S}$, et al. Characterisation of the human uterine microbiome in nonpregnant women through deep sequencing of the V1-2 region of the 16s rRNA gene. PeerJ. (2016) 4:E1602. doi: 10.7717/peerj.1602

18. Walther-António MR, Chen J, Multinu F, Hokenstad A, Distad TJ, Cheek EH, et al. Potential contribution of the uterine microbiome in the development of endometrial cancer. Genome Med. (2016) 8:122. doi: 10.1186/s13073-016-0368-y

19. Miles SM, Hardy BL, Merrell DS. Investigation of the microbiota of the reproductive tract in women undergoing a total hysterectomy and bilateral salpingo-oopherectomy. Fertil Steril. (2017) 107:813-20.e1. doi: $10.1016 /$ j.fertnstert.2016.11.028

20. Khan KN, Fujishita A, Masumoto H, Muto H, Kitajima M, Masuzaki H, et al. Molecular detection of intrauterine microbial colonization in women with endometriosis. Eur J Obstet Gynecol Reprod Biol. (2016) 199:69-75. doi: 10.1016/j.ejogrb.2016.01.040

21. Fang RL, Chen LX, Shu WS, Yao SZ, Wang SW, Chen YQ. Barcoded sequencing reveals diverse intrauterine microbiomes in patients suffering with endometrial polyps. Am J Transl Res. (2016) 8:1581-92.

22. D'Ippolito S, Di Nicuolo F, Pontecorvi A, Gratta M, Scambia G, Di Simone N. Endometrial microbes and microbiome: recent insights on the inflammatory and immune players of the human endometrium. Am J Reprod Immunol. (2018) 80:e13065. doi: 10.1111/aji.13065

23. McQueen DB, Perfetto CO, Hazard FK, Lathi RB. Pregnancy outcomes in women with chronic endometritis and recurrent pregnancy loss. Fertil Steril. (2015) 104:927-31. doi: 10.1016/j.fertnstert.2015.06.044

24. McQueen DB, Bernardi LA, Stephenson MD. Chronic endometritis in women with recurrent early pregnancy loss and/or fetal demise. Fertil Steril. (2014) 101:1026-30. doi: 10.1016/j.fertnstert.2013.12.031

25. Maria M, Cicinelli E, Greco P, Massenzio F, Baldini D, Falagario T, et al. Abnormal pattern of lymphocyte subpopulations in the endometrium of infertile women with chronic endometritis. Am J Reprod Immunol. (2009) 61:322-9. doi: 10.1111/j.1600-0897.2009.00698.x

26. Farland LV, Prescott J, Sasamoto N, Tobias DK, Gaskins AJ, Stuart JJ, et al. Endometriosis and risk of adverse pregnancy outcomes. Obstet Gynecol. (2019) 134:527-36. doi: 10.1097/AOG.0000000000003410

27. Liu Y, Ko EY, Wong KK, Chen X, Cheung WC, Law TS, et al. Endometrial microbiota in infertile women with and without chronic endometritis as diagnosed using a quantitative and reference range-based method. Fertil Steril. (2019) 112:707-17.e1. doi: 10.1016/j.fertnstert.2019.05.015

28. Kunz G, Beil D, Deiniger H, Einspanier A, Mall G, Leyendecker G. The uterine peristaltic pump - normal and impeded sperm transport within the female genital tract. Adv Exp Med Biol. (1997) 424:267-77. doi: 10.1007/978-1-4615-5913-9_49 
29. Donnet-Hughes A, Perez PF, Dore J, Leclerc M, Levenez F, Benyacoub J, et al. Potential role of the intestinal microbiota of the mother in neonatal immune education. Proc Nutr Soc. (2010) 69:407-15. doi: $10.1017 /$ S0029665110001898

30. Jiménez E, Marín ML, Martín R, Odriozola JM, Olivares M, Xaus J, et al. Is meconium from healthy newborns actually sterile? Res Microbiol. (2008) 159:187-9. doi: 10.1016/j.resmic.2007.12.007

31. Srinivasan S, Liu C, Mitchell CM, Fiedler TL, Thomas KK, Agnew KJ, et al. Temporal variability of human vaginal bacteria and relationship with bacterial. PLoS ONE. (2010) 5:e10197. doi: 10.1371/journal.pone.0010197

32. Kroon SJ, Ravel J, Huston WM. Cervicovaginal microbiota, womens health and reproductive outcomes. Fertil Steril. (2018) 110:327-36. doi: 10.1016/j.fertnstert.2018.06.036

33. Ronnqvist PD, Forsgren-Brusk UB, Grahn-Hakansson EE. Lactobacilli in the female genital tract in relation to other genital microbes and vaginal $\mathrm{pH}$. Acta Obstet Gynecol Scand. (2006) 85:726-35. doi: 10.1080/00016340600578357

34. Aldunate M, Srbinovski D, Hearps AC, Latham CF, Ramsland PA, Gugasyan R, et al. Antimicrobial and immune modulatory effects of lactic acid and short chain fatty acids produced by vaginal microbiota associated with eubiosis and bacterial vaginosis. Front Physiol. (2015) 6:164. doi: 10.3389/fphys.2015.00164

35. Ravel J, Gajer P, Abdo Z, Schneider GM, Koenig SS, Mcculle SL, et al. Vaginal microbiome of reproductive-age women. Proc Natl Acad Sci USA. (2011) 108:4680-7. doi: 10.1073/pnas.1002611107

36. Gajer P, Brotman RM, Bai G, Sakamoto J, Schutte UM, Zhong X, et al. Temporal dynamics of the human vaginal microbiota. Sci Transl Med. (2012) 4:132ra52. doi: 10.1126/scitranslmed.3003605

37. Borgdorff $\mathrm{H}$, Verwijs MC, Wit FW, Tsivtsivadze E, Ndayisaba GF, Verhelst R, et al. The impact of hormonal contraception and pregnancy on sexually transmitted infections and on cervicovaginal microbiota in African sex workers. Sex Transm Dis. (2015) 42:143-52. doi: 10.1097/OLQ.0000000000000245

38. Marrazzo JM, Thomas KK, Fiedler TL, Ringwood K, Fredricks DN. Risks for acquisition of bacterial vaginosis among women who report sex with women: a cohort study. PLoS ONE. (2010) 5:e11139. doi: 10.1371/journal.pone.0011139

39. Schwebke JR, Richey CM, Weiss HL. Correlation of behaviors with microbiological changes in vaginal flora. J Infect Dis. (1999) 180:1632-6.

40. Dos Santos Santiago GL, Tency I, Verstraelen H, Verhelst R, Trog M, Temmerman $M$, et al. Longitudinal qPCR study of the dynamics of $L$. crispatus, L. iners, A. vaginae (sialidase positive) G. vaginalis, and P. bivia in the vagina. PLoS ONE. (2012) 7:e45281. doi: 10.1371/journal.pone.0045281

41. Hickey RJ, Abdo Z, Zhou X, Nemeth K, Hansmann M, Osborn TW III, et al. Effects of tampons and menses on the composition and diversity of vaginal microbial communities over time. BJOG. (2013) 120:695-706. doi: 10.1111/1471-0528.12151

42. Achilles SL, Austin MN, Meyn LA, Mhlanga F, Chirenje ZM, Hillier SL. Impact of contraceptive initiation on vaginal microbiota. Am J Obstet Gynecol. (2018) 218:622.e1-10. doi: 10.1016/j.ajog.2018.02.017

43. Brooks JP, Edwards DJ, Blithe DL, Fettweis JM, Serrano MG, Sheth NU, et al. Effects of combined oral contraceptives, depot medroxyprogesterone acetate and the levonorgestrel-releasing intrauterine system on the vaginal microbiome. Contraception. (2017) 95:405-13. doi: 10.1016/j.contraception.2016.11.006

44. Donders GGG, Bellen G, Ruban K, Van Bulck B. Short- and long-term influence of the levonorgestrel-releasing intrauterine system (Mirena ${ }^{\circledR}$ ) on vaginal microbiota and candida. J Med Microbiol. (2018) 67:308-13. doi: 10.1099/jmm.0.000657

45. Van Houdt R, Ma B, Bruisten SM, Speksnijder A, Ravel J, De Vries HJC. Lactobacillus iners-dominated vaginal microbiota is associated with increased susceptibility to chlamydia trachomatis infection in Dutch women: a case-control study. Sex Transm Infect. (2018) 94:117-23. doi: 10.1136/sextrans-2017-053133

46. Spurbeck RR, Arvidson CG. Inhibition of Neisseria gonorrhoeae epithelial cell interactions by vaginal Lactobacillus species. Infect Immun. (2008) 76:3124-30. doi: 10.1128/IAI.00101-08

47. Digiulio DB, Callahan BJ, Mcmurdie PJ, Costello EK, Lyell DJ, Robaczewska $\mathrm{A}$, et al. Temporal and spatial variation of the human microbiota during pregnancy. Proc Natl Acad Sci USA. (2015) 112:11060-5 doi: $10.1073 /$ pnas. 1502875112

48. Elovitz MA, Gajer P, Riis V, Brown AG, Humphrys MS, Holm JB, et al. Cervicovaginal microbiota and local immune response modulate the risk of spontaneous preterm delivery. Nat Commun. (2019) 10:1305. doi: 10.1038/s41467-019-09285-9

49. Hyman RW, Fukushima M, Jiang H, Fung E, Rand L, Johnson B, et al. Diversity of the vaginal microbiome correlates with preterm birth. Reprod Sci. (2014) 21:32-40. doi: 10.1177/1933719113488838

50. Stout MJ, Zhou Y, Wylie KM, Tarr PI, Macones GA, Tuuli MG. Early pregnancy vaginal microbiome trends and preterm birth. Am J Obstet Gynecol. (2017) 217:356.e1-18. doi: 10.1016/j.ajog.2017.05.030

51. Donders GG, Van Bulck B, Caudron J, Londers L, Vereecken A, Spitz B. Relationship of bacterial vaginosis and mycoplasmas to the risk of spontaneous abortion. Am J Obstet Gynecol. (2000) 183:4317. doi: $10.1067 / \mathrm{mob} .2000 .105738$

52. Hay PE, Lamont RF, Taylor-Robinson D, Morgan DJ, Ison C, Pearson J. Abnormal bacterial colonisation of the genital tract and subsequent preterm delivery and late miscarriage. BMJ. (1994) 308:295-8.

53. Llahi-Camp JM, Rai R, Ison C, Regan L, Taylor-Robinson D. Association of bacterial vaginosis with a history of second trimester miscarriage. Hum Reprod. (1996) 11:1575-8.

54. Gibbs RS. Chorioamnionitis and bacterial vaginosis. Am J Obstet Gynecol. (1993) 169:460-2. doi: 10.1016/0002-9378(93)90341-F

55. Hillier SL, Nugent RP, Eschenbach DA, Krohn MA, Gibbs RS, Martin DH, et al. Association between bacterial vaginosis and preterm delivery of a lowbirth-weight infant. The Vaginal Infections and Prematurity Study Group. N Engl J Med. (1995) 333:1737-42.

56. Paramel Jayaprakash T, Wagner EC, Van Schalkwyk J, Albert AY, Hill $\mathrm{JE}$, Money DM, et al. High diversity and variability in the vaginal microbiome in women following preterm premature rupture of membranes (PPROM): a prospective cohort study. PLOS ONE. (2016) 11:e0166794. doi: 10.1371/journal.pone.0166794

57. Koedooder R, Singer M, Schoenmakers S, Savelkoul PHM, Morré SA, de Jonge JD, et al. The vaginal microbiome as a predictor for outcome of in vitro fertilization with or without intracytoplasmic sperm injection: a prospective study. Hum Reprod. (2019) 34:1042-54. doi: 10.1093/humrep/dez065

58. Hyman RW, Herndon CN, Jiang H, Palm C, Fukushima M, Bernstein D, et al. The dynamics of the vaginal microbiome during infertility therapy with invitro fertilization embryo transfer. J Assist Reprod Genet. (2012) 29:105-15. doi: 10.1007/s10815-011-9694-6

59. Garmi G, Okopnik M, Keness Y, Zafran N, Berkowitz E, Salim R. Correlation between clinical, placental histology and microbiological findings in spontaneous preterm births. Fetal Diagn Ther. (2016) 40:141-9. doi: $10.1159 / 000441518$

60. Sweeney EL, Kallapur SG, Gisslen T, Lambers DS, Chougnet CA, Stephenson SA, et al. Placental infection with ureaplasma species is associated with histologic chorioamnionitis and adverse outcomes in moderately preterm and late-preterm infants. J Infect Dis. (2016) 213:1340-7. doi: 10.1093/infdis/jiv587

61. Quinn PA, Butany J, Taylor J, Hannah W. Chorioamnionitis: its association with pregnancy outcome and microbial infection. Am J Obstet Gynecol. (1987) 156:379-87.

62. Moreno I, Simon C. Deciphering the effect of reproductive tract microbiota on human reproduction. Rprod Med Biol. (2019) 18:40-50. doi: $10.1002 / \mathrm{rmb} 2.12249$

63. Han YW. Oral health and adverse pregnancy outcomes-what's next? J Dent Res. (2011) 90:289-93. doi: 10.1177/0022034510381905

64. Aagaard K, Ma J, Antony KM, Ganu R, Petrosino J, Versalovic J. The placenta harbors a unique microbiome. Sci Transl Med. (2014) 6: 237ra65. doi: 10.1126/scitranslmed.3008599

65. Kliman HJ. Comment on the placenta harbors a unique microbiome. Sci Transl Med. (2014) 6:254le4. doi: 10.1126/scitranslmed.3009864

66. Doyle RM, Alber DG, Jones HE, Harris K, Fitzgerald F, Peebles D, et al. Term and preterm labour are associated with distinct microbial community structures in placental membranes which are independent of mode of delivery. Placenta. (2014) 35:1099-101. doi: 10.1016/j.placenta.2014. 10.007 
67. Parnell LA, Briggs CM, Cao B, Delannoy-Bruno O, Schrieffer AE, Mysorekar IU. Microbial communities in placentas from term normal pregnancy exhibit spatially variable profiles. Sci Rep. (2017) 7:11200. doi: 10.1038/s41598-017-11514-4

68. De Goffau MC, Lager S, Salter SJ, Wagner J, Kronbichler A, CharnockJones DS, et al. Recognizing the reagent microbiome. Nat Microbiol. (2018) 3:851-3. doi: 10.1038/s41564-018-0202-y

69. Kim D, Hofstaedter CE, Zhao C, Mattei L, Tanes C, Clarke E, et al. Optimizing methods and dodging pitfalls in microbiome research. Microbiome. (2017) 5:52. doi: 10.1186/s40168-017-0267-5

70. Robertson SA, Moldenhauer LM. Immunological determinants of implantation success. Int J Dev Biol. (2014) 58:205-17. doi: $10.1387 /$ ijdb.140096sr

71. Benner M, Ferwerda G, Joosten I, van der Molen RG. How uterine microbiota might be responsible for a receptive, fertile endometrium. Hum Reprod Update. (2018) 24:393-415. doi: 10.1093/humupd/dmy012

72. Round JL, Lee SM, Li J, Tran G, Jabri B, Chatila TA, et al. The Toll-like receptor 2 pathway establishes colonization by a commensal of the human microbiota. Science. (2011) 332:974-7. doi: 10.1126/science.1206095

73. Zhou L, Chong MM, Littman DR. Plasticity of $\mathrm{Cd} 4^{+} \mathrm{T}$ cell lineage differentiation. Immunity. (2009) 30:646-55. doi: 10.1016/j.immuni.2009.05.001

74. Kaiko GE, Horvat JC, Beagley KW, Hansbro PM. Immunological decision-making: how does the immune system decide to mount a helper T-cell response? Immunology. (2008) 123:326-38. doi: 10.1111/j.1365-2567.2007.02719.x

75. Vaeth M, Wang YH, Eckstein M, Yang J, Silverman GJ, Lacruz RS, et al. Tissue resident and follicular Treg cell differentiation is regulated by CRAC channels. Nat Commun. (2019) 10:1183. doi: 10.1038/s41467-019-08959-8

76. Brown EM, Kenny DJ, Xavier RJ. Gut microbiota regulation of T cells during inflammation and autoimmunity. Annu Rev Immunol. (2019) 37:599-624. doi: 10.1146/annurev-immunol-042718-041841

77. Plitas G, Rudensky AY. Regulatory T cells: differentiation and function. Cancer Immunol Res. (2016) 4:721-5. doi: 10.1158/2326-6066.CIR-16-0193

78. Rudensky AY. Regulatory T cells and Foxp3. Immunol Rev. (2011) 241:260-8. doi: 10.1111/j.1600-065X.2011.01018.x

79. Shevach EM. Cd4 ${ }^{+} \mathrm{Cd} 25^{+}$suppressor T cells: more questions than answers. Nat Rev Immunol. (2002) 2:389-400. doi: 10.1038/nri821

80. Ghiringhelli F, Menard C, Terme M, Flament C, Taieb J, Chaput N, et al. $\mathrm{Cd} 4^{+} \mathrm{Cd} 25^{+}$regulatory $\mathrm{T}$ cells inhibit natural killer cell functions in a transforming growth factor-beta-dependent manner. J Exp Med. (2005) 202:1075-85. doi: 10.1084/jem.20051511

81. Taams LS, Van Amelsfort JMR, Tiemessen MM, Jacobs KMG, De Jong EC, Akbar AN, et al. Modulation of monocyte/macrophage function by human $\mathrm{Cd} 4{ }^{+} \mathrm{Cd} 25^{+}$regulatory T cells. Hum Immunol. (2005) 66:222-30. doi: 10.1016/j.humimm.2004.12.006

82. Lim HW, Hillsamer P, Banham AH, Kim CH. Cutting edge: direct suppression of B cells by $\mathrm{Cd} 4^{+} \mathrm{Cd} 25^{+}$regulatory T cells. J Immunol. (2005) 175:4180-3. doi: 10.4049/jimmunol.175.7.4180

83. Maltepe E, Bakardjiev AI, Fisher SJ. The placenta: transcriptional, epigenetic, and physiological integration during development. J Clin Invest. (2010) 120:1016-25. doi: 10.1172/JCI41211

84. Fowden AL, Forhead AJ, Coan PM, Burton GJ. The placenta and intrauterine programming. J Neuroendocrinol. (2008) 20:439-50. doi: 10.1111/j.1365-2826.2008.01663.x

85. Padidas K, Norwitz E. Implantation. Chapter 4. In: Farquharson RG, Stephenson MD, editors. Early Pregnancy. Cambridge, UK: Cambridge University Press (2017). p. 27-42.

86. Troy E, Kasper D. Beneficial effects of Bacteroides fragilis polysaccharides on the immune system. Front Biosci. (2010) 15:25-34. doi: 10.2741/3603

87. Padidas K, Norwitz E. Implantation. Chapter 4. In: Farquharson RG, Stephenson MD, editors. Early Pregnancy. Cambridge University Press (2017). p. 27-42.

88. Sharkey AM, Dellow K, Blayney M, Macnamee M, Charnock Jones S, Smith SK. Stage-specific expression of cytokine and receptor messenger ribonucleic acids in human preimplantation embryos. Biol Reprod. (1995) 53:974-81.

89. Guzeloglu-Kayisli O, Kayisli UA, Taylor HS. The role of growth factors and cytokines during implantation: endocrine and paracrine interactions. Semin Reprod Med. (2009) 27:62-79. doi: 10.1055/s-00281108011

90. Kwong WY, Wild AE, Roberts P, Willis AC, Fleming TP. Maternal undernutrition during the preimplantation period of rat development causes blastocyst abnormalities and programming of postnatal hypertension. Development. (2000) 127:4195-202.

91. Sjoblom C, Roberts CT, Wikland M, Robertson SA. Granulocytemacrophage colony-stimulating factor alleviates adverse consequences of embryo culture on fetal growth trajectory and placental morphogenesis. Endocrinology. (2005) 146:2142-53. doi: 10.1210/en.2004-1260

92. Robertson SA. GM-CSF regulation of embryo development and pregnancy. Cytokine Growth Factor Rev. (2007) 18:287-98. doi: 10.1016/j.cytogfr.2007.04.008

93. Chin PY, Thompson JG, Robertson SA. A Modest Inflammatory Insult in the Pre-implantation Period Alters Oviduct Cytokine Expression and Programs Fetal Development. Sydney, NSW: Society For Reproductive Biology (2010). p. Abstract 172.

94. Mao G, Wang J, Kang Y, Tai P, Wen J, Zou Q, et al. Progesterone increases systemic and local uterine proportions of $\mathrm{Cd} 4^{+} \mathrm{Cd} 25^{+}$Treg cells during midterm pregnancy in mice. Endocrinology. (2010) 151:5477-88. doi: 10.1210/en.2010-0426

95. Dimitriadis E, White CA, Jones RL, Salamonsen LA. Cytokines, chemokines and growth factors in endometrium related to implantation. Hum Reprod Update. (2005) 11:613-30. doi: 10.1093/humupd/dmi023

96. Vannuccini S, Clifton VL, Fraser IS, Taylor HS, Critchley H, Giudice LC, et al. Infertility and reproductive disorders: impact of hormonal and inflammatory mechanisms on pregnancy outcome. Hum Reprod Update. (2016) 22:104-15. doi: 10.1093/humupd/dmv044

97. Sakaguchi S. Regulatory T cells: key controllers of immunologic selftolerance. Cell. (2000) 101:455-8. doi: 10.1016/S0092-8674(00)80856-9

98. Moldenhauer LM, Hayball JD, Robertson SA. Immune-deviating cytokines determine the maternal $\mathrm{T}$ cell response and conceptus tolerance or rejection. Biol Reprod. (2009) 2:86. doi: 10.1093/biolreprod/81.s1.86

99. Mcintire RH, Hunt JS. Antigen presenting cells and Hla-G-a review. Placenta. (2005) 26:S104-9. doi: 10.1016/j.placenta.2005.01.006

100. Renaud SJ, Graham CH. The role of macrophages in utero-placental interactions during normal and pathological pregnancy. Immunol Invest. (2008) 37:535-64. doi: 10.1080/08820130802191375

101. Rowe JH, Ertelt JM, Xin L, Way SS. Pregnancy imprints regulatory memory that sustains anergy to fetal antigen. Nature. (2012) 490:102-6. doi: $10.1038 /$ nature 11462

102. Searle RF, Jones RK, Bulmer JN. Phenotypic analysis and proliferative responses of human endometrial granulated lymphocytes during the menstrual cycle. Biol Reprod. (1999) 60:871-8.

103. Barnea E. Signaling between embryo and mother in early pregnancy: basis for development of tolerance. In: Carp HJA, editor Recurrent Pregnancy LossCauses, Controversies, and Treatment, 2nd edn. Boca Raton, FL: CRC Press (2014). p. 17-28.

104. Cole LA. Biological functions of HCG and HCG-related molecules. Reprod Biol Endocrinol. (2010) 8:102. doi: 10.1186/1477-7827-8-102

105. Berndt S, Blacher S, D'hauterive PS, Thiry M, Tsampalas M, Cruz $A$, et al. Chorionic gonadotropin stimulation of angiogenesis and pericyte recruitment. J Clin Endocrinol Metab. (2009) 94:4567-74. doi: $10.1210 /$ jc.2009-0443

106. Raga F, Casañ EM, Wen Y, Huang H-Y, Bonilla-Musoles F, Plan ML. Independent regulation of matrix metalloproteinase-9, tissue inhibitor of metalloproteinase-1 (TIMP-1), and TIMP-3 in human endometrial stromal cells by gonadotropin-releasing hormone: implications in early human implantation. J Clin Endocrinol Metab. (1999) 84:636. doi: $10.1210 /$ jc. 84.2 .636

107. Taylor HS, Fritz MA, Pal L, Seli E. Sperm and egg transport, fertilization and implantation. Chapter 6. In: Taylor H, Pal L, Seli E, editors. Speroffs Clinical Gynecologic Endocrinology and Infertility. 9th ed. Philadelphia, PA: Wolters Kluwer (2019). p. 175-95.

108. Pagidas K, Norwitz E. Implantation. Chapter 4. In: Farquharson RG, Stephenson MD, editors. Early Pregnancy. Cambridge University Press (2017). p. 27-42. 
109. Searle RF, Jones RK, Bulmer JN. Phenotypic analysis and proliferative responses of human endometrial granulated lymphocytes during the menstrual cycle. Biol Reprod. (1999) 60:871-8.

110. Pagidas K, Norwitz E. Implantation. Chapter 4. In: Farquharson RG, Stephenson MD, editors. Early Pregnancy. Cambridge University Press (2017). p. 27-42.

111. Pagidas K, Norwitz E. Implantation. Chapter 4. In: Farquharson RG, Stephenson MD, editors. Early Pregnancy. Cambridge University Press (2017). p. 27-42.

112. Norwitz ER. Defective implantation of placentation laying the blueprint for pregnancy complications. Reprod Biomed Online. (2006) 13:591-9. doi: 10.1016/S1472-6483(10)60649-9

113. Krebs C, Macara LM, Leiser R, Bowman AW, Greer IA, Kingdom JC. Intrauterine growth restriction with absent end diastolic flow velocity in the umbilical artery is associated with maldevelopment of the placental terminal villous tree. Am J Obstet Gynecol. (1996) 175:1534-42.

114. Worley LC, Hnat MD, Cunningham FG. Advanced extrauterine pregnancy: diagnostic and therapeutic challenges. Am J Obstet Gynecol. (2008) 198:297.e1. doi: 10.1016/j.ajog.2007.09.044

115. Erlebacher A. Immunology of the maternal-fetal interface. Annu Rev Immunol. (2013) 31:387. doi: 10.1146/annurev-immunol-032712-100003

116. Bdolah Y, Palomaki GE, Yaron Y, Bdolah-Abram T, Goldman M, Levine RJ, et al. Circulating angiogenic proteins in trisomy 13. Am J Obstet Gynecol. (2006) 194:239. doi: 10.1016/j.ajog.2005.06.031

117. Mostello D, Catlin TK, Roman L, Holcomb WL Jr, Leet T. Preeclampsia in the parous woman: who is at risk? Am J Obstet Gynecol. (2002) 187:425. doi: $10.1067 / \mathrm{mob} .2002 .123608$

118. Flint EJ, Cerdeira AS, Redman CW, Vatish M. The role of angiogenic factors in the management of preeclampsia. Acta Obstet Gynecol Scand. (2019) 98:700-7. doi: 10.1111/aogs.13540

119. Johnsen GM, Storvold GL, Drabbels JJM, Haasnoot GW, Eikmans M, Spruyt-Gerritse MJ, et al. The combination of maternal KIR-B and fetal HLA-C2 is associated with decidua basalis acute atherosis in pregnancies with preeclampsia. J Reprod Immunol. (2018) 129:23-9. doi: 10.1016/j.jri.2018.07.005

120. Johnsen GM, Storvold GL, Alnaes-Katjavivi PH, Roald B, Golic M, Dechend $\mathrm{R}$, et al. Lymphocyte characterization of decidua basalis spiral arteries with acute atherosis in preeclamptic and normotensive pregnancies. J Reprod Immunol. (2019) 132:42-8. doi: 10.1016/j.jri.2019.03.003

121. Tersigni C, Redman CW, Dragovic R, Tannetta D, Scambia G, Di Simone N, et al. HLA-DR is aberrantly expressed at feto-maternal interface in preeclampsia. J Reprod Immunol. (2018) 129:48-52. doi: 10.1016/j.jri.2018.06.024

122. Madazli R, Budak E, Calay Z, Aksu MF. Correlation between placental bed biopsy findings, vascular cell adhesion molecule and fibronectin levels in preeclampsia. BJOG. (2000) 107:514. doi: 10.1111/j.1471-0528.2000.tb13271.x

123. Fisher S, Roberts JM. The placenta in normal pregnancy and preeclampsia. In: Taylor RN, Roberts JM, Cunningham FG, editors. Chesley's Hypertensive Disorders in Pregnancy, 4th ed. Amsterdam: Academic Press (2015). p. 81-112.

124. Redman CW, Tannetta DS, Dragovic RA, Gardiner C, Southcombe $\mathrm{JH}$, Collett GP, et al. Review: does size matter? Placental debris and the pathophysiology of pre-eclampsia. Placenta. (2012) 33:S48. doi: 10.1016/j.placenta.2011.12.006

125. Lee SM, Romero R, Lee YJ, Park IS, Park CW, Yoon BH. Systemic inflammatory stimulation by microparticles derived from hypoxic trophoblast as a model for inflammatory response in preeclampsia. Am J Obstet Gynecol. (2012) 207:337.e1. doi: 10.1016/j.ajog.2012.06.047

126. Manten GT, van der Hoek YY, Marko Sikkema J, Voorbij HA, Hameeteman TM, Visser GH, et al. The role of lipoprotein (a) in pregnancies complicated by pre-eclampsia. Med Hypotheses. (2005) 64:162. doi: 10.1016/j.mehy.2004.04.026

127. Owaki Y, Watanabe K, Iwasaki A, Saitou T, Matsushita H, Wakatsuki A. Placental hypoplasia and maternal organic vascular disorder in pregnant women with gestational hypertension and preeclampsia. J Matern Fetal Neonatal Med. (2019) 2:1-7. doi: 10.1080/14767058.2019.1608175
128. Aouache R, Biquard L, Vaiman D, Miralles F. Oxidative stress in preeclampsia and placental diseases. Int J Mol Sci. (2018) 19:e1496. doi: 10.3390/ijms19051496

129. Aquis A, Sultana R, Camenzuli C, Calleja-Agius J, Balzan R. An update of the genetics of preeclampsia. Minerva Ginecol. (2018) 70:465-79. doi: 10.23736/S0026-4784.17.04150-8

130. Nilsson E, Ros HS, Cnattingius S, Lichtenstein P. The importance of genetic and environmental effects for pre-eclampsia and gestational hypertension: a family study. BJOG. (2004) 111:200-6. doi: 10.1111/j.1471-0528.2004.00042x.x

131. Ward K, Taylor RN. Genetic factors in the etiology of preeclampsia. In: Taylor RN, Roberts JM, Cunningham FG, editors. Chesley's Hypertensive Disorders in Pregnancy, 4th ed. Amsterdam: Academic Press (2015). p. 57-80.

132. Apicella C, Ruano CSM, Mehats C, Miralles F, Vaiman D. The role of epigenetics in placental development and the etiology of preeclampsia. Int J Mol Sci. (2019) 20:e2837. doi: 10.3390/ijms20112837

133. Silver RM. Examining the link between placental pathology, growth restriction, and stillbirth. Best Pract Res Clin Obstet Gynaecol. (2018) 49:89102. doi: 10.1016/j.bpobgyn.2018.03.004

134. Brosens I, Benagiano G, Brosens JJ. The potential origin of placentation disorders in the young primi gravida. Am J Obstet Gynecol. (2015) 212:580. doi: 10.1016/j.ajog.2015.01.013

135. Leary PJ, Leary SE, Stout KK, Schwartz SM, Easterling TR. Maternal, perinatal, and post-neonatal outcomes $\mathrm{n}$ women with chronic heart disease in Washington State. Obstet Gynecol. (2012) 120:1283-90. doi: 10.1097/AOG.0b013e3182733d56

136. Schreiber K, Hunt BJ. Pregnancy and antiphospholipid syndrome. Semin Thromb Hemost. (2016) 42:780-8. doi: 10.1055/s-0036-1592336

137. Durie DE, Thronburg LL, Glantz JC. Effect of second-trimester and thirdtrimester rate of gestational weight gain on maternal and neonatal outcomes. Obstet Gynecol. (2011) 118:569-75. doi: 10.1097/AOG.0b013e3182289f42

138. Micali N, Stemann Larsen P, Strandberg-Larsen K, Nybo Andersen AM. Size at birth and preterm birth in women with lifetime eating disorders: a prospective population-based study. BJOG. (2016) 123:1301-10. doi: 10.1111/1471-0528.13825

139. Coker AL, Garcia LS, Williams CM, Crawford TN, Clear ER, McFarlane $\mathrm{J}$, et al. Universal psychosocial screening and adverse pregnancy outcomes in an academic obstetric clinic. Obstet Gynecol. (2012) 119:1180-9. doi: 10.1097/AOG.0b013e318253d76c

140. Holbrook BD, Rayburn WF. Teratogenic risks from exposure to illicit drugs. Obstet Gynecol Clin North Am. (2014) 41:229-39. doi: 10.1016/j.ogc.2014.02.008

141. Sebastiani G, Borras-Novell C, Casanova MA, Tutusaus MP, Martínez SF, Gómez Roig MD, et al. The effects of alcohol and drugs of abuse on maternal nutritional profile during pregnancy. Nutrients. (2018) 10:1008. doi: 10.3390/nu10081008

142. Nie Q, Su B, Wei J. Neurological teratogenic effects of antiepileptic drugs during pregnancy. Exp Ther Med. (2016) 12:2400-4. doi: 10.3892/etm.2016.3628

143. Cyganek A, Pietrzak B, Kociszewska-Najman B. Intrauterine growth restriction in pregnant renal and liver transplant recipients: risk factors assessment. Transplant Proc. (2014) 46:2794-7. doi: 10.1016/j.transproceed.2014.09.001

144. Creasy RK, Resnik R, Iams JD, Lockwood C, Moore T, Greene M, et al. Creasy and Resnik's Maternal-Fetal Medicine: Principles and Practice. 8th ed. Philadelphia, PA: Saunders Elsevier (2019).

145. Desai M, ter Kuile FO, Nosten F, McGready R, Asamoa K, Brabin B, et al. Epidemiology and burden of malaria in pregnancy. Lancet Infect Dis. (2007) 7:93-104. doi: 10.1016/S1473-3099(07)70021-X

146. Toda K, Reef S, Tsuruoka M, Iijima M, Dang TH, Duong TH, et al. Congenital rubella syndrome (CRS) in Vietnam 2011-2012-CRS epidemic after rubella epidemic in 2010-2011. Vaccine. (2015) 33:3673-7. doi: 10.1016/j.vaccine.2015.06.035

147. Picone O, Teissier N, Cordier AG, Vauloup-Fellous C, Adle-Biassette $\mathrm{H}$, Martinovic J, et al. Detailed in utero ultrasound description of 30 cases of congenital cytomegalovirus infection. Prenat Diagn. (2014) 34:518. doi: $10.1002 / \mathrm{pd} .4340$ 
148. Sheffield JS, Sánchez PJ, Morris G, Maberry M, Zeray F, McIntire DD, et al. Congenital syphilis after maternal treatment for syphilis during pregnancy. Am J Obstet Gynecol. (2002) 186:569-73. doi: 10.1067/mob.2002.121541

149. Paquet C, Yudin MH. Toxoplasmosis in pregnancy: prevention, screening, and treatment. J Obstet Gynaecol Can. (2013) 35:78-81. doi: 10.1016/S1701-2163(15)31053-7

150. Selling KE, Carstensen J, Finnstrom O, Sydsjö G. Intergenerational effects of preterm birth and reduced intrauterine growth: a population based-study of Swedish mother-offspring pairs. BJOG. (2006) 113:430-40. doi: 10.1111/j.1471-0528.2006.00872.x

151. Snijders RJ, Sherrod C, Gosden CM, Nicolaides KH. Fetal growth retardation: associated malformations and chromosomal abnormalities. Am J Obstet Gynecol. (1993) 168:547-55.

152. Schemmer G, Wapner RJ, Johnson A, Schemmer M, Norton HJ, Anderson WE. First-trimester growth patterns of aneuploid fetuses. Prenat Diagn. (1997) 17:155-9.

153. Toutain J, Labeau-Gaüzere C, Barnetche T, Horovitz J, Saura R. Confined placental mosaicism and pregnancy outcome: a distinction needs to be made between types 2 and 3. Prenat Diagn. (2010) 30:1155-64. doi: 10.1002/pd.2631

154. Hooper LV, Littman DR, Macpherson AJ. Interactions between the microbiota and the immune system. Science. (2012) 336:1268-73. doi: $10.1126 /$ science. 1223490

155. Thursby E, Juge N. Introduction to the human gut microbiota. Biochem J. (2017) 474:1823-36. doi: 10.1042/BCJ20160510

156. Grice EA, Segre JA. The human microbiome: our second genome. Annu Rev Genomics Hum Genet. (2012) 13:151-70. doi: 10.1146/annurev-genom-090711-163814

157. David LA, Materna AC, Friedman J, Campos-Baptista MI, Blackburn MC, Perrotta A, et al. Host lifestyle affects human microbiota on daily timescales. Genome Biol. (2014) 15:R89. doi: 10.1186/gb-2014-15-7-r89

158. Wang B, Yao M, Lv L, Ling Z, Li L. The human microbiota in health and disease. Engineering. (2017) 3:71-82. doi: 10.1016/J.ENG.2017.01.008

159. Sochocka M, Donskow-Łysoniewska K, Diniz BS, Kurpas D, Brzozowska E, Leszek J. The gut microbiome alterations and inflammation-driven pathogenesis of Alzheimer's disease-a critical review. Mol Neurobiol. (2019) 56:1841-51. doi: 10.1007/s12035-018-1188-4

160. Hajishengallis G. Periodontitis: from microbial immune subversion to systemic inflammation. Nat Rev Immunol. (2015) 15:30-44. doi: $10.1038 /$ nri3785

161. Slocum C, Kramer C, Genco CA. Immune dysregulation mediated by the oral microbiome: potential link to chronic inflammation and atherosclerosis. J Intern Med. (2016) 280:114-28. doi: 10.1111/joim.12476

162. Arimatsu K, Yamada H, Miyazawa H, Minagawa T, Nakajima M, Ryder MI, et al. Oral pathobiont induces systemic inflammation and metabolic changes associated with alteration of gut microbiota. Sci Rep. (2014) 4:4828. doi: $10.1038 /$ srep04828

163. Sato K, Takahashi N, Kato T, Matsuda Y, Yokoji M, Yamada M, et al. Aggravation of collagen-induced arthritis by orally administered Porphyromonas gingivalis through modulation of the gut microbiota and gut immune system. Sci Rep. (2017) 7:6955. doi: 10.1038/s41598-01707196-7
164. Kamada N, Chen GY, Inohara N, Nunez G. Control of pathogens and pathobionts by the gut microbiota. Nat Immunol. (2013) 14:685-90. doi: $10.1038 /$ ni.2608

165. Cario E, Gerken G, Podolsky DK. Toll-like receptor 2 controls mucosal inflammation by regulating epithelial barrier function. Gastroenterology. (2007) 132:1359-74. doi: 10.1053/j.gastro.2007.02.056

166. Yu Y, Lu L, Sun J, Petrof EO, Claud EC. Preterm infant gut microbiota affects intestinal epithelial development in a humanized microbiome gnotobiotic mouse model. Am J Physiol Gastrointest Liver Physiol. (2016) 311:G521-32. doi: 10.1152/ajpgi.00022.2016

167. Cobb CM, Kelly PJ, Williams KB, Babbar S, Angolkar M, Derman RJ. The oral microbiome and adverse pregnancy outcomes. Int $J$ Womens Health. (2017) 9:551-9. doi: 10.2147/IJWH.S142730

168. Minassian C, Thomas SL, Williams DJ, Campbell O, Smeeth L. Acute maternal infection and risk of preeclampsia: a population based case control study. (2013) 8:e73047. doi: 10.1371/journal.pone.0073047

169. Kalinderi K, Delkos D, Kalinderis M, Athanasiadis A, Kalogiannidis I. Urinary tract infection during pregnancy: current concepts on a common multifaceted problem. (2018) 38:448-53. doi: 10.1080/01443615.2017.1370579

170. Den Hollander W, Schalekamp-Timmermans S, Holster IL, Jaddoe VW, Hofman A, Moll HA, et al. Helicobacter pylori colonization and pregnancies complicated by preeclampsia, spontaneous prematurity, and small for gestational age birth. Helicobacter. (2017) 22:e12364. doi: 10.1111/hel.12364

171. Lv LJ, Li SH, Li SC, Zhong ZC, Duan HL, Tian C, et al. Early onset preeclampsia is associated with gut microbial alterations in antepartum and postpartum women. Front Cell Infect Microbiol. (2019) 9:224. doi: 10.3389/fcimb.2019.00224

172. Dunn AB, Hanson L, VandeVusse L, Leslie S. Through the microbial looking glass: premature labor, preclampsia, and gestational diabetes: a scoping review. I Perinat Neonatal Nurs. (2019) 33:35-51. doi: 10.1097/JPN.0000000000000375

173. Amarasekara R, Jayasekara RW, Senanayake H, Dissanayake VH. Microbiome of the placenta in pre-eclampsia supports the role of bacteria in the multifactorial cause of pre-eclampsia. J Obstet Gynaecol Res. (2015) 41:662-9. doi: 10.1111/jog.12619

174. Huang S, Li N, Liu C, Li T, Wang W, Jiang L, et al. Characteristics of the gut microbiota colonization, inflammatory profile, and plasma metabolome in intrauterine growth restricted piglets during the first 12 hours after birth. $J$ Microbiol. (2019) 57:748-58. doi: 10.1007/s12275-019-8690-x

Conflict of Interest: The authors declare that the research was conducted in the absence of any commercial or financial relationships that could be construed as a potential conflict of interest.

Copyright $\odot 2020$ Bardos, Fiorentino, Longman and Paidas. This is an open-access article distributed under the terms of the Creative Commons Attribution License (CC $B Y)$. The use, distribution or reproduction in other forums is permitted, provided the original author(s) and the copyright owner(s) are credited and that the original publication in this journal is cited, in accordance with accepted academic practice. No use, distribution or reproduction is permitted which does not comply with these terms. 